\title{
The Factors of Strategic Leadership on Commitment: An Empirical Banking in Indonesia
}

\author{
Juliansyah Noor \\ STIE La Tansa Mashiro, Banten
}

\begin{tabular}{|c|c|}
\hline ARTICLE INFO & A B S T RACT \\
\hline \multirow[t]{2}{*}{$\begin{array}{l}\text { Keywords: } \\
\text { Organizational Commitment, } \\
\text { Strategic Leadership, } \\
\text { Training, } \\
\text { Organizational Culture, } \\
\text { Ethical Practice. }\end{array}$} & $\begin{array}{l}\text { This research is aimed at obtaining information related to possibility } \\
\text { whether organizational commitment is affected by training, } \\
\text { organization culture, and ethical practice. The data which had been } \\
\text { analyzed by multi regression analysis after all variables had been put } \\
\text { into principal factor analysis. In this research employees were chosen } \\
\text { as a unit analysis and } 120 \text { samples selected randomly. }\end{array}$ \\
\hline & $\begin{array}{l}\text { The result of this study shows that organization commitment is } \\
\text { positively affected by training, organization culture and ethical practice. } \\
\text { Implications of organization commitment might have been effected } \\
\text { by training, organization culture and ethical practice as a strategic } \\
\text { leadership. }\end{array}$ \\
\hline $\begin{array}{l}\text { Corresponding author: } \\
\text { profjul.noor@gmail.com }\end{array}$ & (c) 2013 IRJBS, All rights reserved. \\
\hline
\end{tabular}

\section{INTRODUCTION}

The economic crises are not new. The impact of each crisis varied widely. For example, the Asian country in 1997 had a major impact in the Indonesia. However, the economic crisis that began in the United States in 2007, and in 2010, the financial crisis in Greece roiled the European Union (Gup, 2011).

The banking financial crisis, directly and indirectly affect the sustainability of financial performance.
Therefore, the role of business leaders have the ability to anticipate and directing the crises that may occur. The most effective strategic leaders create viable options in making decisions regarding each of the key strategic leadership actions (O'Toole and Lawler, Jr., 2006), as citied in Hitt et al. (2007). Thus, in order to sustain the performance of the banking, it is required commitment banking leaders to deal with global crisis problems. Commitment is more than just membership, because the commitment consists 
of desire and display effort for the organization (Baron and Armstrong, 2007; Colquitt et al., 2013).

Acknowledging the complexity and the multifaceted nature of antecedents involved in organizational commitment, it is still necessary to understand the dynamics of relationships between these variables.

The main research question is: What is the strategic leadership factors affect on commitment? It is divided sub research question are (1) what is training affected on the commitment? (2) what is organizational culture affected on the commitment? (3) what is ethical practice affected on the commitment?

\section{Literature Review}

\section{Organizational Commitment}

Organizational commitment is defined as an event of individuals interested in the goals, values and goals of the company where he worked. Meyer and Allen, as cited in Biggs and David (2006), states that organizational commitment as a multidimensional work attitude that concerns the bond between the employee and their employing organization. While Meyer and Allen (1997) as cited in Colquitt et al. (2013) classify three motives of commitment organization as "employees with strong affective commitment remain because they want to, those with strong continuance commitment remain because they need to, and those with strong normative commitment because they feel. They ought to do".

Song et al. (2009) found that "dyadic interpersonal trust could influence organizational level collectivistic behaviors, such as organizational commitment, through the collaboration-based learning organizational culture". Song et al. (2009) affirmed the centrality of the dyadic leader-subordinate relationship (LMX) to a variety of organizational outcomes. This means that leaders committed both to their subordinates and organization as a leader commitment.
A leader commitment of banking institutions related to leadership implementation strategies. Strategic leadership is the ability to anticipate, envision, maintain flexibility, and empower others to create strategic change as necessary (Hitt et al., 2007). Because of the global economy's complexity, strategic leaders must learn how to effectively influence human behavior, often in uncertain environments (Hitt et al., 2007). By word or by personal example, and through their ability to envision the future, effective strategic leaders meaningfully influence the behaviors, thoughts, and feelings of those with whom they work (Kotter, 2007). Therefore strategic leadership must be focusing on implementation of training, organizational culture and ethical behavior (Song et al., 2009; Cullinan et al., 2008; Sharma et al., 2009; Bulut and Culha, 2010).

\section{Training}

Bulut and Culha (2010) defined "training is becoming the core element of HR management functions, along with the other HR activities, such as recruitment, selection and reward". Tanova and Nadiri, (2005) identified that "successful HR planning for the future is only possible through sustainable training, which means that organizational training is one of the most important aspects of organizational strategy". Gegenfurtner and Vauras (2012) have suggested that motivation for training represents an important factor in improving the effectiveness of training outcomes that ultimately lead to organizational effectiveness. The motivation will also increase if employees perceive that specific training recommended by the supervisor or management will benefit him/ her in one way or the other (Mattox and Jinkerson, 2005).

One work-related attitude out of many attitudes that is being studied for the relationship of training with management of employee behavior is organizational commitment, a concept that is being studied extensively as an important variable in explaining behaviors related to work because 
it is assumed that it has impact on performance (Aguinis and Kraiger, 2009). Various reports have been given on the positive impact of training on organizational commitment (Boxall and Macky, 2009).

Bulut and Culha (2010) revealed some evidence that benefits of training positively affects organizational commitment. Chiang and Jang (2008) finding that an effective training experience as an indication that the organization is willing to invest in them and cares about them; thus, training may enhance their commitment to the organization. Boon and Arumugam (2006) were found access to organizational training activities is positively related to organization commitment. Thus, the following hypothesis is offered.

\section{$\mathrm{H1}$ : Training is positively affected on organizational commitment}

\section{Organization Culture}

Garibaldi de Hilal (2009) looked organizational culture "refer to some set of meanings and values that members of an organization have". Sisaye (2005) emphasizes that culture thereby performs a functional role by directing instrumental control mechanisms on how best to manage groups. Bhalla and Nazneen (2013) found that the most dominant components of culture were confrontation openness, experimentation, and proactively. They also observed that a culture characterized by high standards of ethics, values, attitude, norms, and organizational climate contributed to the retention of both new hires and existing employees.

Simosi and Xenikou (2010) investigated that an employee show commitment to it work organization when this organization embraces positive group norms. And, it also seems reasonable to suggest that employees who attribute to their organization a constructive orientation are likely to perceive that the risk of leaving the organization are high (Simosi and Xenikou, 2010). In line with Jarnagin and Slocum
(2007) conclude that leaders as culture creators or transformers, high-ranking managers who have the capacity to envision and enact a strong culture with loyalty and commitment.

The behavioral norms and expectations that exist within an organization (organizational culture) explain, in part, differences in the quality of care across organizations and the extent to which service providers report high levels of commitment and satisfaction with their work (Kagaari, 2011). Since culture plays a major part in the way employees react to the new structure of their work environment, ranging from quick adapting and commitment to the new expectations, to resistance, withdrawal and other forms of unproductive behaviors (Garibaldi de Hilal et al., 2009) the identification of the organizational values and practices is a key strategy for cultural management.

\section{H2: Organizational culture is positively affected on organizational commitment.}

\section{Ethical Practice}

Ethical practice refers to right and wrong conduct within a frame of rules and moral principles (Hejase and Tabch, 2012; Ferrell et al., 2011). There are four basic ethical principles namely control and direct the managers' ethical conducts, perceptions and behavior in situations where it is necessary to strike a balance between a company's self-interest and that of its stakeholders (George and Jones, 2009). However, the main purpose of ethical in business is to lead businessmen and businesswomen to abide by the codes of conduct that would help them secure public confidence in the services and products they offer to the concerned stakeholders (Smith et al., 2005). Vitell and Hidalgo (2006) stated that is, the U.S. sample was higher in terms of the organizational factors of corporate ethical values (CEV) and enforcement of a code of ethics, but the Spanish sample was higher in terms of individual factors such as idealism, relativism and commitment to the organization. 
Cullinan et al. (2008) suggest that individuals with higher organizational commitment are consistently significant relationship between organizational commitment and ethical decision making. This relationship holds even for issues in which the organization may benefit in the medium term (i.e., the restructuring charge vignette). Yunus et al. (2011) explore work ethic of Malaysian civil servants. Positive work ethic among others emphasize on hard work, commitment and dedication, and avoidance of wealth accumulation through unethical methods. This ethic is indeed valued by organizations. Employees holding strongly to positive work ethic ensure organization of its goal.

Khan (2012) conclude from empirical results of his study that corporate ethical values positively and significantly affect work related outcomes of job satisfaction, organizational commitment, and organizational citizenship behavior. The study support the hypotheses that organizational commitment to ethical values and integrating these values in work related processes create enabling environment for employees to exhibit high ethical standards with regard to specific work related outcomes. In line with Ebrahim and Ahmadi, (2012), there is significant relationship between professional ethics and organizational commitment and dimensions. Hence, it is hypothesize that;

H3: Ethical practice is positively affected on organizational commitment.

\section{Conceptual Model and Hypotheses}

Based on the literature review and in line with Integrative Model of Organizational Behavior (2013) stated that organizational commitment indirectly influenced by leadership styles and leadership power (Colquitt et al., 2013). While Hitt et al. (2007) suggest in effective strategic leadership factors that managing the firm's resources effectively attempts to illustrate three factors selected in relations with commitment leader, namely; developing human capital, sustain an effective organization culture, and emphasizing ethical practices. Meanwhile, Pearce and Robinson (2007) describe strategic leadership in three factors, consist of training, principles, and perseverance, as shown in Figure 1.

\section{METHODS}

A quantitative survey study was conducted with Branch Banking Manager in Indonesia from January 2014 to April 2014. Overall study population

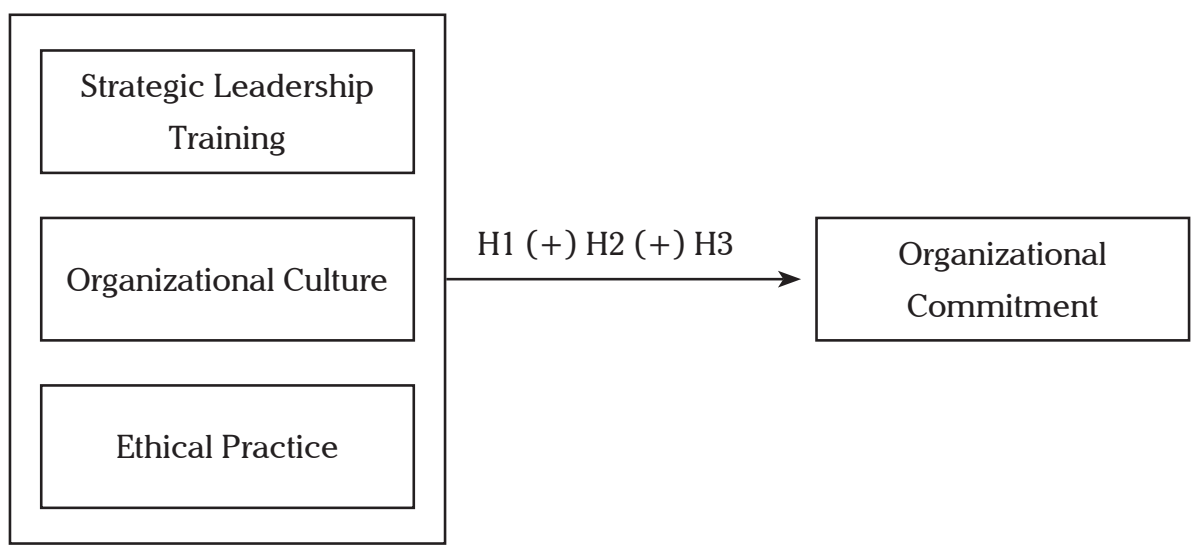

Figure 1. The Strategic Leadership Model

(Modified Models from Colquitt et al., 2013; Hitt et al., 2007; Pearce and Robinson, 2007) 
numbered 265 branch manager. The population for this study consisted of banking manager who served as branch head who have worked in over six years. The population is assumed to be homogeneous. Therefore the results of this study represents the strategic leadership of banking in Indonesia banking companies as a whole.

Whenever possible, multi-items within each construct were developed and adapted from existing scales previously validated within literature. All items were measured using fivepoint Likert scales representing a range from one strongly disagree to five strongly agree.

This study adapts Chambel and Sobral's (2011) training associated transmit knowledge and promote, employee staying in organization, and improving employee work performance. Organization culture construct was operationalized using three items that are adapted and modified from by Hofstede (1997) as cited Garibaldi de Hilal et al. (2009). The measure consists of employee's loyalty, continuously improved performance, and pay and bonus system. Ethical practice construct comes from Kalshoven et al. (2011). It consists of three items in relation to integrity related codes of conduct, terms of behaving with integrity, and discussion on integrity issues. Commitment organization construct was operationalized from measure developed and validated by Kohtamaki et al. (2012) associated tasks based on strategy, commit to implementing strategy, and executes the planned strategy.

The instrument was validated by panel of academics. The instrument was then put through a two way language translation process to ensure that the translation to Indonesia language was valid. The instrument was also validated for ease of answer by fifteen branch banking and pilot tested to thirty branch banking heads randomly selected from the population of banker.

The questionnaire was mailed to 265 branch banking heads registered. The final number of usable responses was 206, i.e., a response rate of 45.3 percent. Sixty-five percent of the branch banking heads have been in business for more than six years from private bank. Twenty-eight percent of the respondents from government bank, and seven percent from foreign bank.

Principal component analysis was performed. All constructs appeared to be reliable and valid. Hence, individual item reliability for all constructs was further assessed by examining the simple correlations of the measures with their respective constructs using SPSS program. All items of the constructs were above the 0.50 cut-off values recommended. Furthermore, the results of the principal component analysis as shown in Table 1.

\section{RESULTS AND DISCUSSIONS}

Results of this study were evaluated using the Statistical Package for the Social Sciences (SPSS) version 20.0 for Windows. Throughout the statistical analysis, significance level of 0.05 was taken into consideration. Descriptive statistics was used to present the main characteristics of the sample. For the factor structure of the scales, factor.

In this study all the items related to strategic

Table 1. KMO and Bartlett's Test

\begin{tabular}{|l|l|r|}
\hline \multicolumn{2}{|l|}{ Kaiser-Meyer-Olkin Measure of Sampling Adequacy. } & .666 \\
\hline \multirow{3}{*}{ Bartlett's Test of Sphericity } & Approx. Chi-Square & 59.614 \\
\cline { 2 - 3 } & df & 3 \\
\cline { 2 - 3 } & Sig. & .000 \\
\hline
\end{tabular}


leadership (training, organizational culture and ethical practice) were taken together in the factor analysis. It was seen that KMO value was 0.666 and Bartlett's Test of Sphericity was significant ( $p=0.000<0.001)$; which indicated that the data was adequate and appropriate to conduct factor analysis. As a result of factor analysis of all strategic leadership items, revealed three factors named training, organizational culture, and ethical practice by strategic leadership.

The mean scores computed in Table 2 are based on weighted average method. In the 5-point scale these mean values represent somewhat positive level of Indonesian Banker. Among all the factors commitment has got highest mean value of 3,506 ( ${ }=0,883)$. This means Indonesian Banker are moderate satisfied with that factor practices by the Banking and it is well accepted by all the employees. From the characteristics of the data, it is observed that the data of organization culture $(\mu$ $=3.364, \mathrm{\partial}=.959)$ is highly deviated from the mean among all other factors. This statistical evidence implies that this factor involved in the practice of the banking are not adequately designed for all the employee. Thus, the banking should build and internalization their organization culture. On the other hand, the data of training ( $\mu=3.433$, $\partial=.869$ ) has been found less deviated from the mean. This statistics indicates that the banking has been successfully maintaining good training which is appreciated by all level of the employee positions.

In the table, a significant positive and strong correlation was found for the organizational commitment in relationship with training ( $\mathrm{r}$ $=.538, \mathrm{p}<.05)$, with organizational culture $(\mathrm{r}$ $=.629, \mathrm{p}<.05)$, and also with ethical practice $(\mathrm{r}=.494, \mathrm{p}$ <.05). This significant correlation indicates that these factors have strong influence on organizational commitment of the banking. All factors have a positive and strong correlation which implies the banking should develop and implement a strategic leadership that has complete synchronization among those factors.

\section{Principal Factor Analysis}

In Table 3, the results show that those three factors explain reliability analysis, the three factors (Cronbach's $\alpha$ training $=0.866, \alpha$ organizational culture $=0.903$, $\alpha$ ethical practice $=0.781$ ) indicate high internal consistency. Organizational culture exhibit as the most important factor that contains more information than any of other factors loaded with explains $83,81 \%$ variance, which indicates that it provides the maximum insights of commitment of the banking industry. Hence, the policy makers of this organization ought to enhance friendly culture and policies in order to retain their key employees. The second most important factor here is training. Training itself explains 78,88\% variance of the dependent variable organizational commitment. So, the organization must continue do the training of employee to take their valued for the long time which is ultimate target for a learning organizational. The others strategic leadership factors for the study were ethical practice, which constitute the factor account for $70,68 \%$ of the variance in the data attitudes.

Table 2. Means, Standart Deviation, and Correlation for Variables

\begin{tabular}{lcccccc}
\hline Factors & Mean & Std.Dev & TR & OC & EP & OCM \\
\hline TR & 3.4334 & .86931 & 1 & $.189^{*}$ & $.475^{* *}$ & $.538^{* *}$ \\
OC & 3.3642 & .95949 & $.189^{*}$ & 1 & .143 & $.367^{* *}$ \\
EP & 3.2556 & .94675 & $.475^{* *}$ & .143 & 1 & $.469^{* *}$ \\
OCM & 3.5056 & .88358 & $.538^{* *}$ & $.367^{* *}$ & $.469^{* *}$ & 1 \\
\hline
\end{tabular}


Analysis was performed with principal components model and factor loadings were taken into consideration. For the internal consistency of the scales, reliability analysis was performed and coefficient alphas were taken into consideration. Before the regression analysis, in order to test the relationships among factors and the variables, bivariate correlations were conducted. To test the hypotheses, multiple and simple regression analyses were used.

\section{Multiple Regression Analysis}

Results are shown in Table 4. In the table, only the significant variables are shown with their respective regression coefficients $(\beta s)$, standard errors, B and computed student's t statistics along with their respective significance level. Results of the regression analysis revealed that out of three variables, such as training, organizational culture, and ethical practice relationship had statistically significant effects on organizational commitment. These results are also consistent with the results found in the factor analysis.

To examine the effect between variables, multiple regression analysis is done. It is seen in Table 4, a stronger positive affect between training on organizational commitment and has been found ( $\beta$ $=0.414, p=0.00$ ). In this sense the first hypothesis of the research, which suggests a significant affect between training on organizational commitment is partially supported.

Organizational culture is found to have a strong affect with organizational commitment ( $\beta=0.216$, $\mathrm{p}=0.02$ ). According to this result, hypothesis 2 is said to be supported. It means organizational commitment is affected by organizational culture.

Table 3. Factor Analysis: Strategic Leadership Factors Affect Organizational Commitment

\begin{tabular}{|c|c|c|c|c|}
\hline Factor Name & Indicators & $\begin{array}{l}\text { Factor } \\
\text { Loading }\end{array}$ & $\begin{array}{l}\% \text { of variance } \\
\text { (Cumulative) }\end{array}$ & $\begin{array}{c}\text { Cronbach's } \\
\text { Reliability } \\
\text { Coefficient }\end{array}$ \\
\hline \multirow{3}{*}{ Training } & $\begin{array}{l}\text { Transmit Knowledge and } \\
\text { Promote }\end{array}$ & .914 & \multirow{3}{*}{78.884} & \multirow{3}{*}{.866} \\
\hline & $\begin{array}{l}\text { Employee Staying in } \\
\text { Organizational }\end{array}$ & .905 & & \\
\hline & $\begin{array}{l}\text { Improving Employee Work } \\
\text { Performance }\end{array}$ & .843 & & \\
\hline \multirow{3}{*}{$\begin{array}{l}\text { Organizational } \\
\text { Culture }\end{array}$} & Employees Loyalty & .897 & \multirow{3}{*}{83.810} & \multirow{3}{*}{.903} \\
\hline & $\begin{array}{l}\text { Continuously Improved } \\
\text { Performance }\end{array}$ & .927 & & \\
\hline & Pay and Bonus System & .922 & & \\
\hline \multirow{3}{*}{ Ethical Practice } & $\begin{array}{l}\text { Integrity Related Codes of } \\
\text { Conduct }\end{array}$ & .935 & \multirow{3}{*}{70.675} & \multirow{3}{*}{.781} \\
\hline & Terms of Behaving With Integrity & .943 & & \\
\hline & Discussion on Integrity Issues & .597 & & \\
\hline \multirow{3}{*}{$\begin{array}{l}\text { Commitment } \\
\text { Organizational }\end{array}$} & Tasks Based on Strategy & .902 & \multirow{3}{*}{80.378} & \multirow{3}{*}{.877} \\
\hline & Commit to Implementing Strategy & .916 & & \\
\hline & Executes the Planned Strategy & .871 & & \\
\hline
\end{tabular}


Table 4. Results of Multiple Regression

\begin{tabular}{lccc}
\hline Factors of Strategic Leadership & $\beta$ & Tstat & Sig. \\
\hline Training & .414 & 5.175 & .000 \\
\hline Organization Culture & .216 & 3.142 & .002 \\
\hline Ethical Practice & .236 & 2.750 & .007 \\
\hline Constant & .592 & & \\
\hline $\mathrm{R}^{2}=.401$ & & & \\
$\Delta \mathrm{R}^{2}=.386$ & & & \\
$\mathrm{~F}=25.926$ & & & \\
$\mathrm{~N}=120$ & & & \\
\hline
\end{tabular}

Whereas organizational commitment is affected is positively significant with ethical practice $(\beta$ $=0.236, \mathrm{p}=0.07)$. Thus, the third hypothesis which assumes that ethical practice affected on organizational commitment is partially supported.

The coefficients of different variables are evident in the above estimated regression equation. Stepwise regression indicates the calculated value for $\mathrm{R}^{2}=$ 0.410 , which means that the eight independent variables in the regression equation together explain $40,10 \%$ of the variation in the dependent variable namely organizational commitment. The value for $\Delta \mathrm{R}^{2}=0.386$ is the value of the co-efficient of determination adjusted for degree of freedom. It states that when adjusted for degree of freedom, the eight independent variables explain 38,60\% of the variation in the dependent variable. These values for $R^{2}$ and $\Delta R^{2}$ further support the stepwise regression findings.

\section{MANAGERIAL IMPLICATIONS}

Much attention has been given to the impact of the organizational behaviour on organization commitment as an outcomes in the HRD field, with focus on the training, organization culture, and ethical practice effect on the organizational commitment. The concept of the organization commitment is closely related to culture aspects and ethical practice that individual has a higher levels of organizational commitment identify more strongly with their organization (Song et al., 2009; Cullinan et al., 2008).

This research contributes to theoretical knowledge about strategic leadership of branch banking heads in respect to factors affecting commitment organization, namely training, organizational culture and ethical practice of these human resources development. In so doing, the research also has a range of managerial implications.

The first major finding result indicate that branch banking heads are confident that is employee training can be increasing organization commitment. It was also identified that they lack business skill. Second, Employees commitment may address through organizational culture. Thus, banking management in implementing the strategic leadership in culture development need to involve comprehensive human resource development activities which often include assignments of branch managers to headquarters. Third, the results underline the need for banking management to consider how ethical practice can be pursued more effectively. An important aspect of the employee of bank is identifying and developing potential them, entailing providing on the job training and mentoring to bank managers in areas such as organizational culture and ethical practice. 


\section{CONCLUSION}

Researcher found positive results for all three research questions. First, training showed positive effect on organization commitment. Second, organization culture is positively effect on organization commitment. Third, ethical practice in banking management play the role to explain the organizational commitment. Most significantly in this final result, a large amount of the effect of training in predicting the perceived level of the organizational commitment. This research contributes to the emerging literature on banking staffing, the writer acknowledge has limitations. First, our study used a quantitative survey approach; hence, our findings reflect perception of branch heads in each branches. Future research might involve in-depth case studies in selected organizations, which would entail a range of interviews with decision-makers at headquarters, branches and sub branches, and supported by bank documentation.

\section{REFERENCES}

Aguinis, H. and Kraiger, K. (2009). Benefits of training and development for individuals and teams, organizations, and society. Annual Review of Psychology, 60, 451-74.

Baron, A. and Armstrong, M. (2007). Human capital management: Achieving added value through people. London: Kogan Page Publishers.

Bhalla, P. and Nazneen, A. (2013). A study of organizational culture in Indian organized retail sectors. International Journal of Retail Management and Research, 3(1), 1-6.

Biggs, D. and Swailes, S. (2006). Relations, commitment and satisfaction in agency workers and permanent workers. Employee Relations, 28 (2), 130-143.

Boon, O. K. and Arumugam, V. (2006). The influence of corporate culture on organizational commitment: Case study of semiconductor organizations in Malaysia. Sunway Academic Journal, 3, 99-115.

Boxall, P. and Macky, K. (2009). Research and theory on high-performance work system: progressing the high-involvement stream. Human Resource Management Journal, 19 (1), 3-23.

Bulut, C. and Culha, O. (2010). The effects of organizational training on organizational commitment. International Journal of Training and Development. 14:4, pp. 309-322.

Chambel, M.J. and Sobral, F. (2011). Training is an investment with return in temporary workers A social exchange perspective. Career Development International, Vol. 16 No. 2, pp. 161-177.

Chiang, C. F. and Jang, S. C. (2008), An expectancy theory model for hotel employee motivation. International Journal of Hospitality Management, 27, 2, pp. 313-22.

Colquitt, J.A, Lepine, J.A and Wesson, M.J. (2013). Organization behavior. Singapore: McGraw-Hill.

Cullinan, C., Bline, D., Farrar, R., Lowe, D. (2008). Organization-harm vs. organization-gain ethical issues: an exploratory examination of the effects of organizational commitment. Journal of Business Ethics. 80, pp. 225-235.

Ferrell, O.C., Fraedrich, J. and Ferrell, L. (2011). Business ethics: Ethical decision making and cases. Ohio: South-Western.

Ebrahim, G. and Ahmadi, S.A.A. The study of relationship between professional ethics and personnel's organizational commitment of Bu Ali Sina Petro Chemistry Company. Interdisciplinary Journal of Contemporary Research in Business, Vol 3, No 10, pp. 771-787.

Gegenfurtner, A. and Vauras, M. (2012). Age-related differences in the relation between motivation to learn and transfer of training in adult continuing education. Contemporary Educational Psychology, 37, 33-46.

Garibaldi de Hilal, A.V., Wetzel, U., and Ferreira, V. (2009). Organizational culture and performance: a Brazilian case. Management Research News, Vol. 32, No. 2, pp. 99-119. 
George, J.M. and Jones, G. (2012). Understanding and managing organizational behavior. New Jersey: Prentice Hall.

Gup, B.E. (2011). Banking and financial institutions: A guide for directors, investors, and counterparties. New Jersey: John Wiley and Sons.

Hejase, H.J. and Tabch, H. (2012). Ethicals education an assessment case of the american university of science and technologyLebanon. International Journal of Islamic and Middle Eastern Finance and Management, 5 (2), pp. 116-133.

Hitt, M.A., Ireland, R.D. and Hoskisson, R.E. (2007). Strategic management: Competitiveness and globalization. Ohio: SouthWestern.

Jarnagin, C. and Slocum Jr., J.W. (2007). Creating corporate cultures through mythopoetic leadership. Organizational Dynamics, 36 (3), 288-302.

Kagaari, J.R.K. (2011). Performance management practices and managed performance: the moderating influence of organisational culture and climate in public universities in Uganda. Measuring Business Excellence, Vol. 15, No. 4, pp. 36-49.

Kalshoven, K., Den Hartog, D.N. De Hoogh, A.H.B. (2011). Ethical leadership at work questionnaire (ELW): Development and validation of a multidimensional measure. The Leadership Quarterly, (22), pp. 51-69.

Khan, M.A. (2012). Ethical values and work related outcomes: An empirical study of Pakistani organizations. African Journal of Business Management, Vol. 6(11), pp. 3977-3987.

Kohtamaki, M., Kraus, S., Makela, M., Ronkko, M. (2012). The role personnel commitment to strategy implementation and organizational learning within the relationship between strategic planning and company performance. International Journal of Entrepreneurial Behaviour \& Research, Vol. 18, No. 2, pp. 159-178.

Kotter, J.P. (2007). Leading change why transformation efforts fail. Harvard Business Review, 1-10.

Mattox, J.R. and Jinkerson, D.L. (2005). Using survival analysis to demonstrate the effects of training on employee retention. Evaluation and Program Planning, 28 (4), 423-430.

Pearce, J.A. And Robinson, R.B. (2007). Formulation, implementation and control of competitive strategy. New York: McGrawHill.

Sharma, D., Borna, S., Stearns, J.M. An investigation of the effects of corporate ethical values on employee commitment and performance: examining the moderating role of perceived fairness. Journal of Business Ethics, 89, pp. 251-260.

Simosi, M. and Xenikou, A. (2010). The role of organizational culture in the relationship between leadership and organizational commitment: an empirical study in a Greek organization. The International Journal of Human Resource Management, 21 (10), 1598-1616.

Sisaye, S. (2005). Management control systems and organizational development: New directions for managing work teams. Leadership \& Organization Development Journal. 26 (1), pp. 51-61.

Smith, M.L., Smith, K.T. and Mulig, E.V. (2005). Application and assessment of an ethicals presentation for accounting and business classes. Journal of Business Ethicals, 61, 153-64.

Song, J.H., Kim, H.M., Kolb, J.A. The effect of learning organization culture on the relationship between interpersonal trust and organizational commitment. Human Resource Development Quarterly, Vol. 20, No. 2, pp. 147-167.

Tanova, C. and Nadiri, H. (2005), 'Recruitment and training policies and practices: the case of turkey as an EU candidate', Journal of European Industrial Training, 29, 9, pp. 694-711.

Vitell, S.J. and Hidalgo, E.C. (2006). The impact of corporate ethical values and enforcement of ethical codes on the perceived importance of ethics in business: a comparison of U.S. and Spanish managers. Journal of Business Ethics. 64, pp. 31-43.

Yunus, O.M. (2011). Work ethic of Malaysian civil servants. 2nd International Conference on Business and Economic Research (2nd icber 2011). Proceeding, pp. 225-238. 